\title{
HOW EFFECTIVE IS EMPOWERING MSMES THROUGH BUSINESS TRAININGS? A LESSON FROM DAYA PROGRAM OF BANK BTPN
}

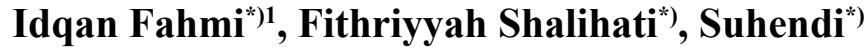 \\ *) School of Business, IPB University \\ Jl. Pajajaran, Bogor 16151, Indonesia
}

\begin{abstract}
Bank BTPN has a unique program called Daya aiming to grow the business of its MSME customers by giving free regular and systematic business trainings. The question is how effective is the Daya program in improving the business of its MSME customers. The effectiveness is shown by comparing business performances of participating MSME customers with non-participating ones. The study had been undertaken in 12 BTPN working areas by surveying 545 numbers of participants and 111 numbers of nonparticipants. The results showed that the Daya program had a positive direct impact on MSMEs' business variables such as turnover, operational cost and customers' business growth index (CBGI), especially at the micro-enterprises category. Indirectly, the trainings also have a good impact on MSME's family and environment reflected by changes in household expenditure (family) and number of employees (environment). Finally, the Daya program's has improved the quality of business practices of participating MSMEs in the aspects of managing finance, marketing, sales, human resources, operations and soft-skills.
\end{abstract}

Keywords: empowering MSMEs, business trainings, business variables, customers' business growth index, micro-enterprises

\begin{abstract}
Abstrak: Bank BTPN memiliki program unik bernama DAYA yang bertujuan untuk menumbuhkan bisnis nasabah UMKM dengan memberikan pelatihan bisnis secara berkala dan sistematis secara gratis. Pertanyaannya adalah seberapa efektif program DAYA dalam meningkatkan bisnis nasabah UMKM nya. Efektivitas ditunjukkan dengan membandingkan kinerja bisnis nasabah UMKM yang berpartisipasi dengan yang tidak berpartisipasi. Penelitian dilakukan di 12 wilayah kerja BTPN dengan mensurvei 545 jumlah partisipan dan 111 non partisipan. Hasil penelitian menunjukkan bahwa Daya program berdampak langsung positif terhadap variabel usaha UMKM seperti omzet, biaya operasional dan indeks pertumbuhan usaha nasabah (CBGI), khususnya pada kategori usaha mikro. Secara tidak langsung pelatihan juga berdampak baik bagi keluarga dan lingkungan UMKM yang tercermin dari perubahan pengeluaran rumah tangga (keluarga) dan jumlah pegawai (lingkungan). Terakhir, Daya program telah meningkatkan kualitas praktik bisnis UMKM peserta dalam aspek pengelolaan keuangan, pemasaran, penjualan, sumber daya manusia, operasional dan soft-skill.
\end{abstract}

Kata kunci: pemberdayaan UMKM, pelatihan bisnis, variabel bisnis, indeks pertumbuhan bisnis pelanggan, usaha mikro

\footnotetext{
${ }^{1}$ Corresponding author:

Email: ifahmi.mk@gmail.com/ifahmi@apps.ipb.ac.id
} 


\section{INTRODUCTION}

MSMEs in Indonesia possess problems that include internal and external factors. Internal factors are the obstacles that come from the business. Problems included in internal factors include: (1) Lack of Capital, (2) Limited Human Resources (HR), and (3) Weak Business Networks and Market Penetration Capabilities. The problem of external factors is a constraint that affects the course of a business that comes from outside the business. Problems included in external factors are (1) The Business Climate is not yet fully conducive, (2) Limited Business Facilities and Infrastructure, (3) Implications for Regional Autonomy, (4). Implications of Free Trade, (5) The Nature of the Product with a Short Lifetime, (6) Limited Market Access (Hafsah, 2004), (Efforts to Develop Small and Medium Enterprises (SMEs) by Dr. Ir. Mohammad Jafar Hafsah in Infokop number 25 years XX, 2004).

Banking institutions are one of the institutions that have a role in efforts to develop and grow MSMEs in the country, namely through capital assistance (Chakrabarty, 2012). In addition, no less important than capital assistance is the development and improvement of soft skills or the capacity of MSME entrepreneurs (Odhiambo, 2013; Rohayati and Wulandari, 2017; Alam and Dunan, 2019). This is important to increase competitiveness so that it can survive and is expected to compete in the domestic and foreign markets (Indrawan et al, 2013; Shrotriya and Dhir, 2018).

The role of banks in MSME financing continues to show a significant increase from year to year (Chakrabarty, 2012). As a Bank that is committed to developing the Micro \& Small Business (MSE) business, BTPN has a vision to be the best mass market bank in Indonesia, so of course the main segments of BTPN are the lowincome segment and the micro and small business segment. In realizing this vision, the empowerment and capacity building of customers is integrated and integrated with the credit program, the Business Growth Program (DTU). So that customers not only receive credit, but also receive training facilities and business information in one package.

The Daya Tumbuh Usaha program (DTU) has three subprograms, namely: 1) a monthly business information bulletin that contains buying and selling information related to MSE businesses, designed to promote the business of customers; 2) business skills training for MSE customers; and 3) new business opportunities that connect large companies with customers through a franchise system.

This study focuses on the extent of the impact of the DTU program on changes in turnover, operational costs, household, environment and customers' business growth index (CBGI) by comparing recipients of the DTU program and non-program recipients (noncustomers), and also looked at the extent to which participant and non-participant business management (financial, marketing, production, human resources, sales, softskills) has improved.

\section{METHODS}

The Impact of the Daya Tumbuh Usaha Program (DTU) is carried out for customers who have participated and who have not participated in training programs in the national scope (represented by 12 regions in Indonesia). The time required to carry out these activities is for 5 (five) calendar months.

Data and information collected are qualitative and quantitative data. The study aims to see the extent of the impact of the DTU program on changes in turnover, operational costs, household, environment and customers' business growth index (CBGI), the quality of business practices by comparing DTU program participants and non- participants (non-customers). Data obtained from surveys and in-depth interviews in the field with program beneficiary customers, as well as other data and information obtained from agencies / institutions related to the purpose of the study.

The types of data used in this study are: 1) Primary data, this data was obtained from respondents who were sampled from the population of program recipient customers (participant); 2) Secondary data, this data is obtained from various sources relevant to the purpose of the study.

Respondents were divided into 2 (two) groups, namely respondents who participated (participant) in the DTU Program as many as 545 respondents and respondents who did not participate in the DTU Program (control group/non-participant) as many as 111 respondents. Respondents who participated in the 
DTU Program (participant) were classified by type of business (grocery, food stalls, textile or shoe stores, cellphone and accessories stores, workshops, and other businesses) and were divided into 12 regions (Medan, Pekanbaru, Palembang, Jakarta, Bandung, Semarang, Solo, Surabaya, Malang, Mataram, Makassar and Banjarmasin). Respondents who are divided by type of business, divided again by scale of business (micro, small and medium). This business scale division is based on RI Law No.20 of 2008, which divides business scale based on annual income. More details can be seen in Table 1.

Table 1. Business Scale Based on RI Law No.20 of 2008

\begin{tabular}{ll}
\hline $\begin{array}{l}\text { Bussiness } \\
\text { Scale }\end{array}$ & Revenue (Turnover) / Year \\
\hline Micro & $\leq \mathrm{Rp} 300.000 .000$ \\
Small & $\geq \mathrm{Rp} 300.000 .000$ until $\leq \mathrm{Rp} 2.500 .000 .000$ \\
Medium & $\geq \mathrm{Rp} 2.500 .000 .000$ until $\leq \mathrm{Rp} 50.000 .000 .000$ \\
\hline
\end{tabular}

The collection of primary data and information in this study was carried out by direct interviews with respondents. Interviews were conducted with a guide to a structured questionnaire. The type of questions used in the questionnaire is a combination of open-ended and closed-ended questions. While secondary data and information were obtained from various sources relevant to the study.

The data and information that have been collected are then tabulated and analyzed in both quantitative and qualitative analysis, which are then described narrative, image and matrix, so that the results of the analysis are complete and complete in accordance with the objectives of the study. Specifically, the data analysis methods in this study are: 1) Descriptive Statistic Analysis; 2) Customer Business Growth Index (CBGI), which is defined as a number that describes changes relative to the growth of business indicators compared to the base year. In the DTU Program, CBGI can be approached from indicators of the development of Micro, Small and Medium Enterprises. One indicator of the development of Micro, Small and Medium Enterprises is to look at business growth (revenue growth, production growth, profit growth, asset growth, and loan growth). CBGI can be formulated as follows:

$C B G I=a\left[\frac{A t}{A_{0}}\right]+b\left[\frac{B t}{B_{0}}\right]+c\left[\frac{C t}{C_{0}}\right]+d\left[\frac{D t}{D_{0}}\right]+e\left[\frac{E t}{E_{0}}\right]$
Description: A (Revenue); B (Production); C (Profit); $\mathrm{D}$ (Asset); E (Loan); t (year to t); 0 (base year; a, b, c, d, e (weight). Note: Weights are obtained using the Pairwise Comparison Method. The research framework can be seen in Figure 1.

\section{RESULTS}

This research was conducted on customers who participated in the DTU Program (Training, Business Information or New Business Opportunities) and who had followed the program for at least 2 years (to see the impact of the DTU Program) as well as those who did not attend the DTU program, by comparing the DTU program participant respondents with non-participant respondents intended to see how far the impact of the program.

\section{Impact of Daya Tumbuh Usaha (DTU) on Business (Direct and Indirect)}

One of the objectives of the Daya Tumbuh Usaha Program (DTU) is to encourage customer business improvement. This research can capture the impact of DTU on customers 'businesses as seen from changes in respondents' income and changes in business operating costs.

Percentage of Respondents Experiencing Changes in National Turnover (Direct Impact)

A business can be said to develop if there is an increase in the turnover (income) that the customer gets regardless of other factors. This shows the addition of volume or type of product offered. Changes in the number of respondents receiving the program (participant) experienced an increase in business turnover by $75 \%$ per year, and the rest of the recipient respondents who experienced a decrease in turnover $(11.33 \%)$ and did not experience a change in turnover $(13.77 \%)$, while the percentage of control respondents (non-participant) who experienced an increase in business turnover was smaller than the percentage of participant respondents (69.37\%). For non-participant who experienced a decrease, it has a smaller percentage than the percentage of participant. The percentage of respondents who did not experience a change in turnover (fixed) in the nonparticipant was higher than the participant. 
Based on Figure 2, percentage of respondent experiencing an increase in business turnover were higher for participants compared to non-participant. This shows that the DTU program has contributed to increasing the turnover of their participant. Based on Figure 3, overall average increase in business turnover of programs participant is greater than non-participant, especially for micro business with $24,07 \%$.

Of all participant who experienced an increase in business turnover (75\%), 53.24\% had an increase in business turnover of up to Rp250,000,000.00, and the percentage of respondents whose business turnover increased from Rp250,000,000.00 - Rp500,000,000.00 by $21.22 \%$ (Figure 4 ). This is in accordance with research respondents who mostly have micro scale businesses.

The largest distribution of respondents who experienced an increase in turnover in control respondents (non-participant) was in the range of $\mathrm{Rp}>$ 0 to $\mathrm{Rp} 250,000,000.00$, the same condition as recipient respondents (Figure 5). The number of respondents who experienced an increase in turnover of more than Rp 1 billion in control respondents was higher than respondents in the program participants.

Percentage of Respondents Experiencing Changes in National Operating Costs (Direct Impact)

One way to find out the success of the DTU Program, can be seen its impact on changes in customer operating costs is to compare changes in operational costs of customers who have joined the DTU program with a control group (non-recipients of the DTU program). From the national data, the number of respondents receiving the program experienced an increase in operational costs by $68.35 \%$. and the rest of the recipient respondents experienced a decrease in operational costs $(5.40 \%)$ and did not experience changes in operational costs $(26.26 \%)$. While the percentage of control respondents (non-recipients) who experienced an increase in business operating costs is smaller than the percentage of recipient respondents $(65.79 \%)$. For control customers who experienced a decrease, they had a higher percentage than the percentage of recipient respondents $(6.14 \%)$. The percentage of respondents who did not experience changes in operational costs (fixed) in the control respondents was higher than the respondents receiving (participants) the program (28.07\%). Based on Figure 6 respondents who experienced an increase in operational costs for recipient respondents were higher than nonparticipants customers. The number of respondents who experienced a decrease in operational costs to the non-participants group customers was greater than the non-participants. The increase in operational costs in this study could not be determined as a negative impact, and vice versa, whether the reduction in operational costs was a positive impact, so studies were needed. further to find out the causes of increase and decrease in both income and operating costs.

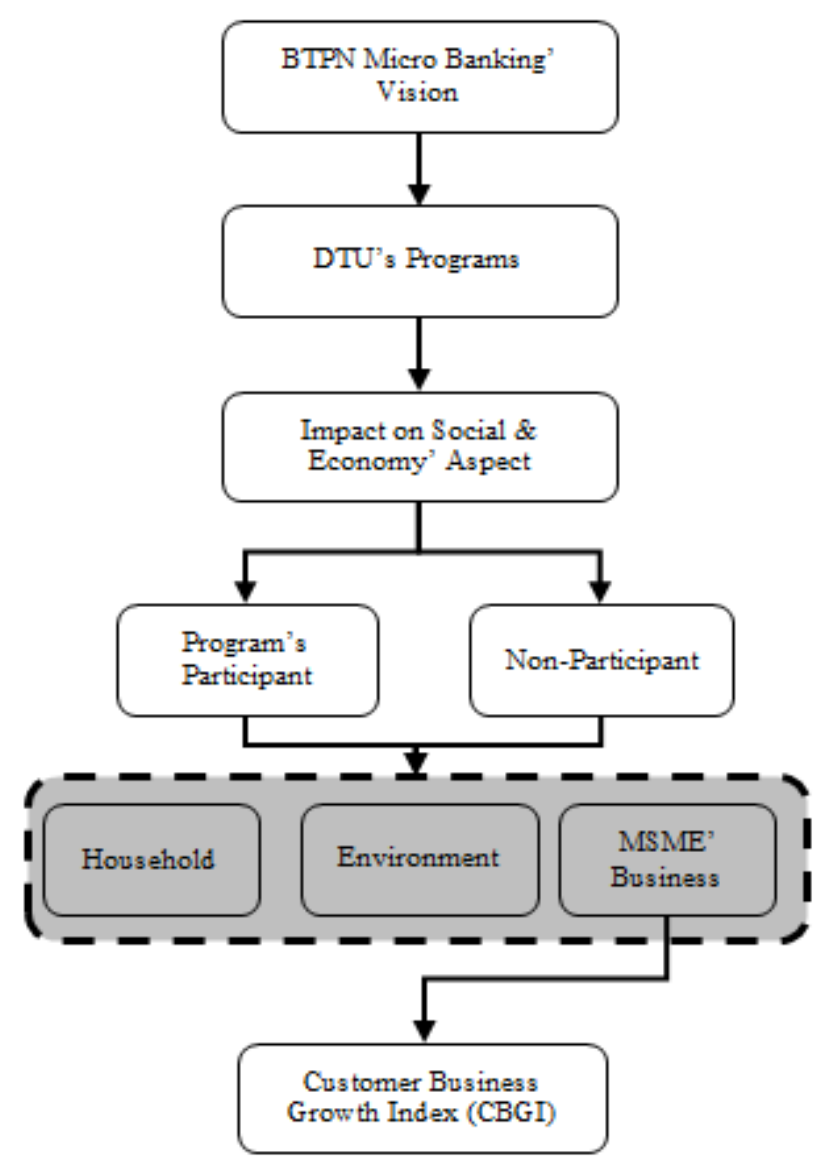

Figure 1. Research Framework

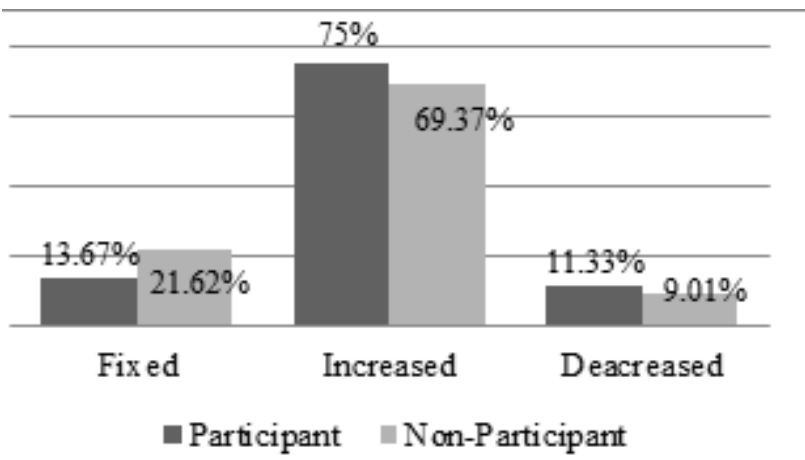

Figure 2. Percentage of respondents to change in turnover per year 


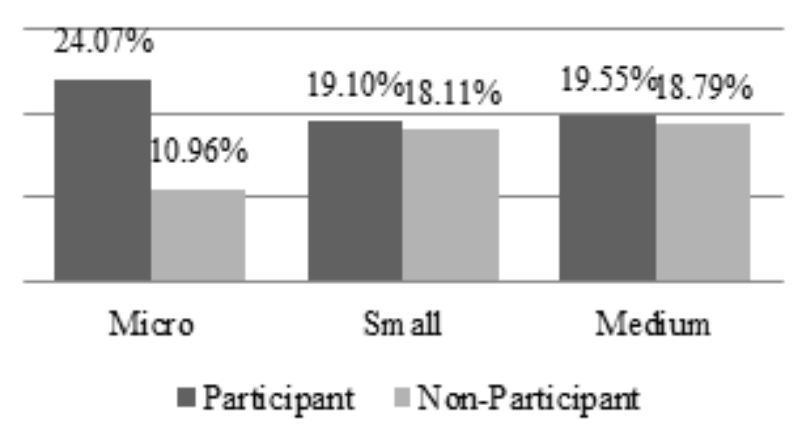

Figure 3. Average percentage of change in turnover expenditures per business scale

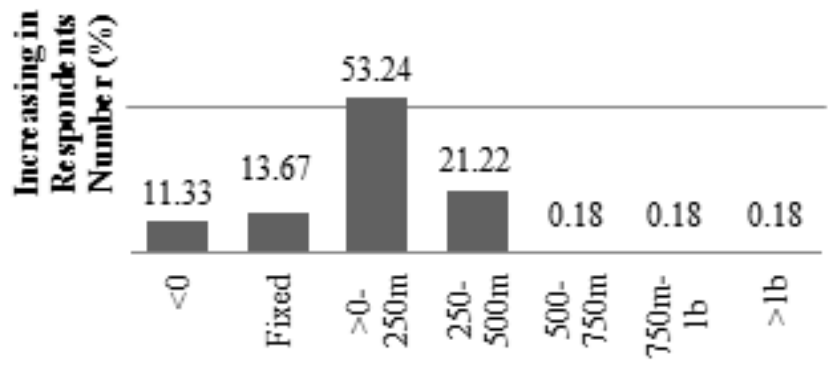

Figure 4. Percentage of respondents to change in turnover (recipient respondents)

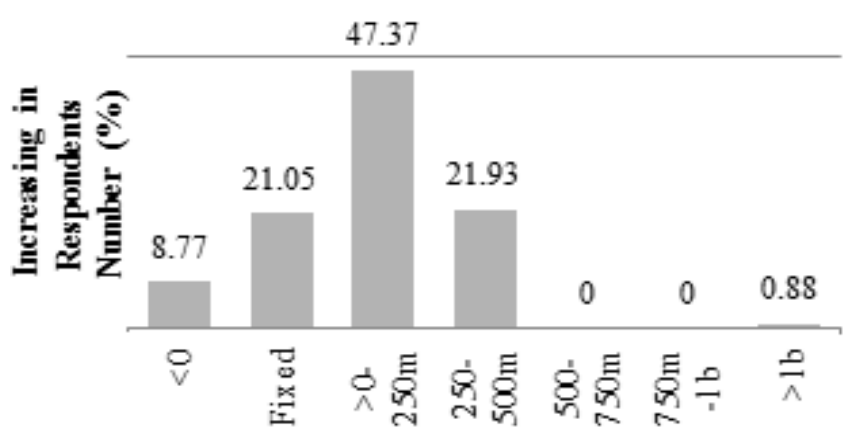

Figure 5. Percentage of respondents to change in turnover (non-recipient respondents)

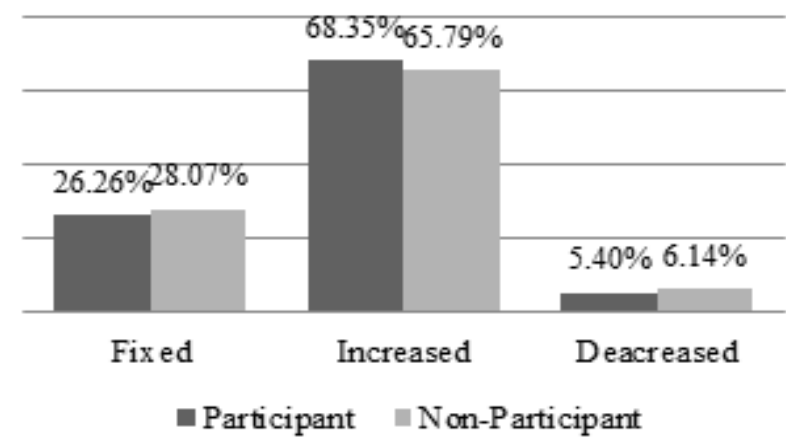

Figure 6. Percentage of respondents to changes in operating costs
Majority of respondents were experiencing an increase in operating cost with participants had a higher percentage. This may be caused by the increase in business activity as shown by the impact on business turnover. Further study is needed, however, as around $30 \%$ also stated that their operating cost were either decreased or not changed.

Nationally, on the receiving customers, the largest percentage of customers who experienced an increase in operational costs was those who experienced an increase of Rp. 0 - Rp. 250,000,000 in the amount of $56.83 \%$. Whereas respondents who experienced an increase above $250,000,000$ were only around $11 \%$. Similar to the group of program participants, the largest percentage of customers in the non-participants group were respondents who experienced an increase in operational costs in the range of Rp.0 - Rp. 250,000,000. Based on Figure 7, overall, average increase in operational cost of program participant is greater than non-participant (the largest is micro with $28,58 \%$ ).

Impact of Daya Tumbuh Usaha (DTU) on Households (Indirect Impact)

The impact of the DTU Program can also be seen from the customer's household expenses. After being analyzed, the DTU Program has an impact on respondents' household expenditure as shown in Figure 8. From this figure the number of participants has increased household expenditure by $60.07 \%$ and who has not experienced changes in household expenditure (fixed) by 37, 59\% while those who experienced a decrease in number were only slightly at $2.34 \%$. While the percentage of non-participants who experienced an increase in business operating costs was greater than the percentage of participants $(70.18 \%)$. For non-participants who did not experience changes in household expenditure were smaller when compared with participants $(27.19 \%)$ while respondents who experienced a decrease, had a higher percentage than the percentage of participants $(2.63 \%)$.

When viewed on a business scale (micro, small, and medium) the impact of the DTU program on changes in household expenditure can be seen in Figure 9. On the micro scale the value of changes in household expenditure on respondents receiving DTU programs (participants) is smaller than those of non-participants of DTU programs. The percentage change in household expenditure on the micro-scale recipient of the DTU 
program is $27 \%$ while that of non-recipients of the DTU program is $36 \%$. On a small business scale, the value of changes in household expenditure of participants is greater than non-participants by only a difference of $3 \%$. Where changes in the value of household expenditure on participants by $28 \%$ while in non-participants by $25 \%$. On a medium business scale, like the small scale, the value of changes in household expenditure of participants is greater than that of nonparticipants. On a medium scale the average percentage change in household expenditure on a medium scale is $48 \%$ while non-participants are $31 \%$.

Impact of Daya Tumbuh Usaha (DTU) on the Environment

The impact of the DTU program on the environment can be seen from changes in the number of workers and changes in working hours of employees. From the results of the analysis, it was found that the number of workers both respondents who participated the DTU program and non-participants of the DTU program was relatively unchanged (fixed). The percentage of respondents whose number of workers did not change in the group of participants was $85.50 \%$, the number was smaller compared to the number in the non-participants group (89.47\%) (Figure 10). The percentage of respondents whose workforce experienced an increase in participants was $9.91 \%$, the number was higher when compared to non-participants $(9.65 \%)$. While the percentage of respondents who experienced a decrease in the number of workers in participants was $4.59 \%$, the number was higher when compared to non-participants $(0.88 \%)$.

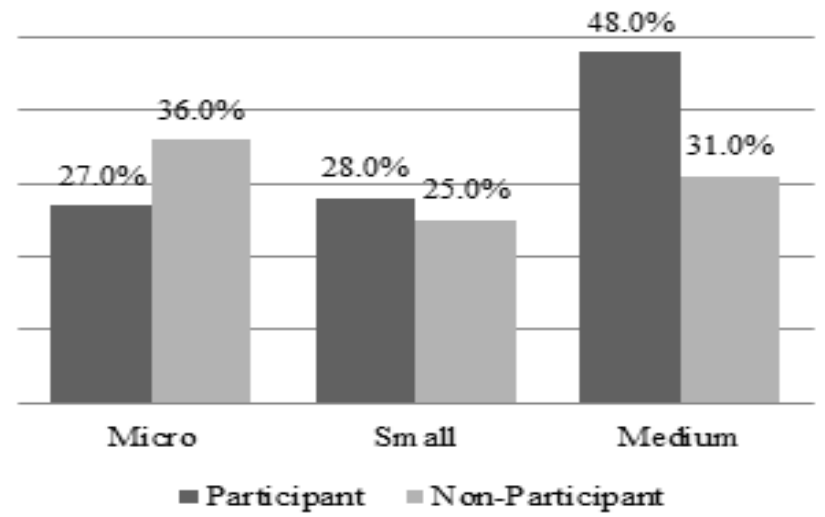

Figure 9. Average percentage of change in household expenditures per business scale

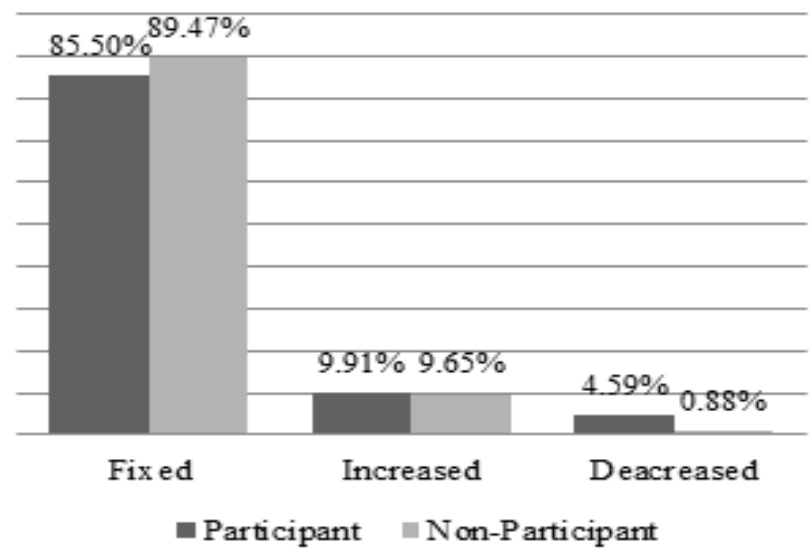

Figure 10. Percentage of respondents to changes in the number of workers 


\section{Customer Business Growth Index (CBGI)- Direct Impact on Business}

Customer Business Growth Index (CBGI), which is defined as a number that describes changes relative to the growth of business indicators compared to the base year. In the DTU Program, CBGI can be approached from indicators of the development of Micro, Small and Medium Enterprises. One indicator of the development of Micro, Small and Medium Enterprises is to look at business growth (revenue growth, production growth, profit growth, asset growth, and loan growth). CBGI defined with two part, based on business scales (Table 2 ), and based on business type (Table 3 ).

Overall, the data showed an increase in business for program participants, when compared to the previous year and compared to non-participants in the same year. Nationally, the CBGI without labor (real) 1.385, without labor (nominal) 1.384, and with labor 1.385. Those number is higher than non-participants who were only $1.303,1.291$, and 1.311 , sequentially.

This study also looked at the extent to which participant and non-participant business management has improved. Table 4 shows that the percentage of the number of participants who did financial management tends to be higher than that of non-participants. Participants better understand and apply training for materials in marketing management, sales management, production management, HR management, and soft skills, especially in materials that are more in-depth and complicated when compared to non-participants. For more details (Table 4).
By comparing the recipients of the DTU program with the Non-recipient, it can be seen how far the program has an impact on customers. The direct impact of the DTU Program on the customer's business can be seen in the turnover (income) and operational costs of the customers obtained. The number of respondents who experienced an increase in turnover for recipient customers $(75.00 \%)$ was greater than the nonrecipient group customers $(69.37 \%)$. The percentage of respondents who experienced an increase in turnover was greater than respondents who remained and declined. The largest distribution of respondents who experienced an increase in turnover for program recipient customers and non-program recipients was in the range of $\mathrm{Rp}>0-250$ million. The percentage of respondents who increased the most was respondents who attended 3 types of training. For the micro scale, the more participating in the type of training, the higher the percentage increase in turnover, but the peak is in 3 types of training. For small and medium scale, there is a tendency to increase turnover percentage after following more than 3 types (Inmyxai and Takahashi, 2010). The percentage of respondents who experienced an increase in turnover was greater than respondents who remained and declined. The highest percentage of respondents whose turnover increased was respondents who attended 3 types of training. For the micro scale, the largest percentage increase in turnover was found in respondents who attended 3 training sessions, and experienced a decrease in frequency of more than 3 times the training. For the small scale, the more training participants take, the turnover value also decreases. For medium scale, there is a tendency to increase turnover percentage after more than 3 training sessions.

Table 2. CBGI based on business scale

\begin{tabular}{lcccc}
\hline \multirow{2}{*}{ Business Scale } & \multicolumn{2}{c}{ CBGI Participants } & \multicolumn{2}{c}{ CBGI Non-Participants } \\
\cline { 2 - 5 } & Without Labor/ Workers & With Labor/ Workers & Without Labor/ Workers & With Labor/ Workers \\
\hline Micro & 1.353 & 1.359 & 1.321 & 1.348 \\
Small & 1.309 & 1.322 & 1.255 & 1.268 \\
Medium & 1.491 & 1.52 & 1.296 & 1.318 \\
National & 1.384 & 1.385 & 1.291 & 1.311 \\
\hline
\end{tabular}




\begin{tabular}{lcccc}
\hline \multirow{2}{*}{ Business Type } & \multicolumn{2}{c}{ CBGI Participants } & \multicolumn{2}{c}{ CBGI Non-Participants } \\
\cline { 2 - 5 } & $\begin{array}{c}\text { Without Labor/ } \\
\text { Workers }\end{array}$ & $\begin{array}{c}\text { With Labor/ } \\
\text { Workers }\end{array}$ & $\begin{array}{c}\text { Without Labor/ } \\
\text { Workers }\end{array}$ & $\begin{array}{c}\text { With Labor/ } \\
\text { Workers }\end{array}$ \\
\hline Grocery & 1.266 & 1.252 & 1.28 & 1.271 \\
Food Stalls & 1.353 & 1.362 & 1.07 & 1.15 \\
Textile/ Shoe Stores & 1.244 & 1.149 & 1.60 & 1.778 \\
Cellphone \& Accessories Stores & 1.802 & 1.812 & 1.72 & 2.083 \\
Workshop (Car\& Motorcycle Repair) & 1.338 & 1.276 & 1.11 & 1.142 \\
Other Businesses (Services) & 1.347 & 1.308 & 1.34 & 1.315 \\
\hline
\end{tabular}

Table 4. Business management improvement

\begin{tabular}{llcc}
\hline Training / Learning Materials & & Participant (\%) & Non-Participant (\%) \\
\hline Financial & Financial Planning & 66.24 & 61.4 \\
& Financial Separation & 80.37 & 68.42 \\
& Financial Records & 78.53 & 69.3 \\
Production & Financial Statements & 54.13 & 47.37 \\
& Arrangement Of Goods & 85.32 & 85.96 \\
& Stock & 90.28 & 90.35 \\
& Reducing Unsold Items & 66.61 & 55.26 \\
Marketing & Adding Types Of Goods & 71.19 & 59.65 \\
& Branding & 77.06 & 83.33 \\
& Promotion Tools & 35.41 & 32.46 \\
Human Resources (HR) & Unique Selling Point & 49.91 & 44.74 \\
& Who \& What Consumer Needs & 79.08 & 69.3 \\
& Jobdesk & 87.52 & 90.35 \\
Sales & Improving Employee' Ability & 72.29 & 74.56 \\
& Encourage Employees To Perform & 76.88 & 78.95 \\
& Promotion Package & 42.39 & 44.74 \\
& Types of Sales & 39.45 & 35.09 \\
Softskill & Loyal Customer & 72.29 & 64.04 \\
& Increasing Businesses Turnover Through & 33.21 & 27.19 \\
& Promotion Packages & & \\
& Business Goals & 96.15 & 92.11 \\
& Business Diciplines & 93.21 & 90.35 \\
& Business Adaptation & 60.92 & 57.89 \\
\hline
\end{tabular}

The number of respondents who experienced an increase in operational costs for recipient customers was greater than for non-recipient group customers. The number of respondents who experienced a decrease in operational costs for non-recipient group customers was greater than the recipient customers. The largest distribution of respondents who experienced an increase in operational costs for program recipient customers and non-program recipients was in the range of $\mathrm{Rp}>0-250$ million. The percentage of respondents who experienced an increase in operational costs was greater than the respondents who remained and declined. The highest percentage of respondents who increased operational costs were respondents who attended 3 types of training. For micro scale, the biggest percentage increase in operational costs is found in respondents who attend 3 types of training. For small scale, there are respondents who follow $>3$ types, and medium scale there are respondents who take 2 types of training. The percentage of respondents who experienced an increase in operational costs was greater than the respondents who remained and declined. The percentage of respondents who increased operational costs at most was respondents who had attended 3 training sessions. For the micro scale, the largest percentage increase in operational costs is found 
in respondents who attended 2 training sessions. For small scale, there are respondents who participated $>$ 3 times, and medium scale found in respondents who participated in 3 times training.

The indirect impact of the DTU program can be seen from household and environmental expenditure (the number of workers and working hours). The number of respondents who experienced an increase in household spending on recipient customers was smaller than the non-recipient group of program customers. The number of respondents who experienced an increase in household spending on recipient customers was smaller than the non-recipient group of program customers. On a Micro scale the increase in the value of household expenditure for program recipient customers is smaller than for non-program recipients. Whereas on a Medium scale the increase in the value of household expenses of recipient customers is greater than nonrecipient programs. Most of the program recipients and non-recipients have a fixed workforce from the previous year. Similar to other capability enhancement programs, DTU has improved the quality of business practices of participating MSMEs in the aspects of managing finance, marketing, sales, human resources, operations and soft-skills (Mapherson and Wilson, 2003).

\section{Managerial Implications}

As a priority program, The Daya Tumbuh Usaha program (DTU) has to enhance their methods and delivery which is not limited to business information bulletin that contains buying and selling information, business skills training, and business matching opportunities. Instead, more actions and efforts are needed to ensure the MSME clients are gaining more benefit from this program (Chakrabarty, 2012). This is the next strategic agenda for DTU. It has to be created in the form of MSMEs Empowerment and Development Strategy Model (Alam and Dunan, 2019). First, DTU should play a more partnership role rather than just connection between financing company and their client. It implies BTPN to enhance the program as a multi-stakeholder platform to ensure sustainable business development (Mudde et al, 2012; Odhiambo, 2013;). By this effort, BTPN could enhance the MSME with competitiveness and MSME will comply with global standard to become a key player in the global value chain (Fadillah et al,
2019). Second, the enhancement strategy by BTPN should focus on MSEM human capital investment in industry 4.0 via technology and engineering. It will be beneficial, especially for many MSME Indonesia which is typically known as a family business with limited access to technology and engineering (Rohayati and Wulandari, 2017; Anggraini et al, 2019). The technology improvement is vital for MSME to be ready in digital era. Not to mention, this readiness is the key for MSME to be part of global business (Tirdasari et al, 2019). By increasing their capability, BTPN will increase the MSME income and growth. Therefore, this agenda that focus on the MSME human capital in industry 4.0 will improve MSME ability in designing and improving compensation system (Kartika and Indrawan 2019a; Kartika and Indrawan 2019b; Nugraha et al, 2020). Third, technology improvement for the MSME needs an IoT business model to upgrade their business (Fadillah and Indrawan, 2020; Hasanah and Indrawan, 2020). However, this is not the only urgency in digitalization or their readiness for IoT. Since the MSME has to improve their capability in other managerial area.

\section{CONCLUSIONS AND RECOMMENDATIONS}

\section{Conclusions}

DTU as business training for MSME was found effective to empower MSME. DTU impact in improving the quality of business practices for the participating MSMEs in their program was proven as an important program for BTPN. It increased many aspects of MSEM management skills such as finance, marketing, sales, human resources, operations and softskills which are led to changes in turnover, operational costs, household, environment and customers' business growth index (CBGI).

\section{Recommendations}

The comparison between recipients of the DTU program and non-program recipients (non-customers) strengthens these findings. Therefore, DTU continuance is important but not limited in extending the program. It has to be in the form of a next strategic agenda for BTPN. 


\section{REFERENCES}

Alam IA, Dunan H. 2019. MSMEs Empowerment and Development Strategy Model. Review of Integrative Business and Economics Research 8:324.

Analisis Dampak Program Daya Tumbus Usaha BTPN Mitra Usaha Rakyat. 2013

Anggraini RI, Tirdasari NL, Indrawan D. 2020. Family Business Challenge in Technology and Engineering: Human Capital in Industrial 4.0. InFirst ASEAN Business, Environment, and Technology Symposium (ABEATS 2019) 2020 May 18 (pp. 83-86). Atlantis Press.

Chakrabarty KC. 2012. Empowering MSMEs for Financial Inclusion and Growth-Role of Banks and Industry Associationsll. change. 2012;9(4785.27):32-08.

Fadillah A, Indrawan D, Achsani NA. 2019. Indonesian Coffee in The Global Value Chain: The Comparison of Global Partnership Sustainability Standards Implementation. Jurnal Manajemen \& Agribisnis 16(2):191.

Fadillah A, Indrawan D. 2020. IoT Business Model Development for Food Safety Monitoring System in the Poultry Slaughterhouse. InIOP Conference Series: Materials Science and Engineering 2020 Jun 1 (Vol. 874, No. 1, p. 012022). IOP Publishing.

Hasanah N, Indrawan D. 2020. Food Safety Monitoring System using IoT in the Poultry Slaughterhouse. InIOP Conference Series: Earth and Environmental Science 519(1): 012043.

Indrawan D, Syaefudin A, Alim SS. 2013. Strategi UpGrading dari manajemen rantai pasok menuju manajemen rantai nilai untuk menangani harga dan volume pasokan komoditas sapi dalam Ketahanan pangan. Orange Book 2013: Ekonomi dan manajemen Ketahanan Pangan. Bogor: Fakultas Ekonomi dan Manajemen IPB

Inmyxai S, Takahashi Y. 2015. The effect of firm resources on business performance of maleand female-headed firms in the case of Lao micro-, small-, and medium-sized enterprises (MSMEs). International Journal of Business and Information 5(1).

Jafar HM. 2004. Upaya Pengembangan Usaha Kecil dan Menengah (UKM). Infokop Nomor 25 Tahun XX.
Kartika L, Indrawan D. 2020. Designing Compensation System for Culinary Business: The Case of Bogor City, West Java Province, Indonesia. InFirst ASEAN Business, Environment, and Technology Symposium (ABEATS 2019) 2020 May 18 (pp. 116-119). Atlantis Press.

Kartika L, Indrawan D. 2020. Identification of Compensation System in Culinary Business: The Case of Bogor City, West Java Province, Indonesia. InFirst ASEAN Business, Environment, and Technology Symposium (ABEATS 2019) 2020 May 18 (pp. 26-29). Atlantis Press.

Macpherson A, Wilson A. 2003. Enhancing SMEs' capability: opportunities in supply chain relationships?. Journal of Small Business and Enterprise Development Jun 1.

Mudde H, Indrawan RD, Fahmi I. 2012. Multisector Partnerships For Sustainable Business Development: Lessons Learned From Round Table Indonesia. Jurnal Manajemen \& Agribisnis 9(2):7-18.

Nugraha DF, Pratama IM, Kustiawan M. 2020. Financial Satisfaction Increase: Effect of Income and Financial Literacy Factors (Study of MSMEs). In3rd International Conference on Research of Educational Administration and Management (ICREAM 2019) 2020 Feb 7 (pp. 320-322). Atlantis Press.

Odhiambo AA. 2013. Factors influencing performance of youth owned micro, small and medium enterprises (MSME) in Kenya. International Journal of Social Sciences and Entrepreneurship 1(3):263-272.

Rohayati Y, Wulandari S. 2017. Training needs analysis for MSMEs: how to improve training effectiveness. InIOP Conference Series: Materials Science and Engineering 277(1): 012030.

Shrotriya S, Dhir S. 2018. MSME Competitiveness for the Global Value Chain-A TRIZ-Based Approach. InGlobal Value Chains, Flexibility and Sustainability 2018: 33-46.

Tirdasari NL, Indrawan D, Fahmi I. 2019. Family Business in Agriculture: Challenge and Strategy to Face Global Business. InInternational Conference on Trade 2019 (ICOT 2019) 2019 Sep. Atlantis Press. 